\title{
Exploring the Effects of Service Quality, Shipping Cost, Brand and Attitude on Consumer's Intention to Choose Express Courier Services in E-Commerce
}

\author{
Wiryanta Muljono \\ Graduate School of Communication Sciences InterStudi, Indonesia ${ }^{1}$ \\ Sri Setiyawati \\ Graduate School of Economics, Sebelas Maret University, Indonesia
}

Received: 23 September 2019 / Revised: 06 November 2019 / Accepted: 13 November 2019 / Published online: 31 December 2019

\begin{abstract}
The growth of e-commerce has highlighted the importance of express courier service (ECS). We empirically study consumer's choice of ECS in purchasing goods online. This research aims to examine the effect of service quality (SQ), shipping cost, brand, and attitude towards customers' intention to choose ECS on e-commerce. This research was conducted using a quantitative approach among customers who intended their goods to be shipped using ECS. Data of 100 respondents were collected and then analyzed using the structural equation model technique. We find that there is no correlation between SQ and shipping cost and the attitude towards choosing a courier service. However, the analysis indicates that brand has an influence on the customer's attitude towards choosing a courier service. Furthermore, the analysis suggests that the consumer's attitude towards choosing a courier service acts as a mediator between SQ, shipping cost, and brand as regards the consumer's intention to choose an ECS. It is worth noting that brand has a stronger influence on the consumer's attitude compared to the former factors.
\end{abstract}

JEL classification: M39; Y90

Keywords: service quality, shipping cost, brand, attitude, intentions, express courier service, e-commerce.

\section{INTRODUCTION}

The growth and evolution of the e-commerce sector has highlighted the importance of courier services for business models that involve a connection between consumers and retailers. The existence of an obvious separation between customers and products creates opportunities for courier business that are not present in conventional retailing.

The rapid growth of e-commerce has also revolutionized relationships within startups, courier services and consumer transaction settings. Further, it has influenced the business development

Corresponding author: Wiryanta Muljono, Senior Lecturer of Digital Economy, Graduate School of Communication Sciences InterStudi. Jalan Wijaya II No. 62 Kebayoran Baru, Jakarta 12160, Indonesia.

Phone: +628178501, e-mail: wiryantamuljono@gmail.com or wiryanta@kominfo.go.id 
of shipping companies, one of them is SiCepat Ekspres, which is focused on serving online shopping. SiCepat Ekspres currently serves around 40,000-50,000 package shipments per day. SiCepat Ekspress has also worked with around 4,600 Small and Medium Enterprises (SMEs) that run their businesses online. The company is also working with 10 e-commerces and large online marketplaces such as MatahariMall.com, Tokopedia, Bukalapak, JakMall, and PlanetSurf Online (InvestorDaily, 2017). We are interested in reviewing the SiCepat courier as a multinational company because it ranks fourth most in favor of customers and as a newcomer (founded in 2014) it has high customer growth.

Competitive advantage is likely to depend on market orientation, in the sense that a service provider should be able to attend to the consumer's wants and needs. In this case, ECS should be able to cater for the consumer's needs and address consumer orientation. Therefore, the phenomenon of the attitude and intention to choose ECS in e-commerce as a novelty of technology adoption is an interesting issue to study.

Witnessing the strong growth of e-commerce, academics have directed increasing attention to e-commerce research because unlike traditional commerce, e-commerce does offer an option regarding the courier service that delivers the items purchased. For this reason, a number of challenges have been addressed. This study highlights the potential challenges associated with achieving success in courier services and proposes relevant recommendations to overcome them.

A behaviour-based explanation shows that there is inconsistency between attitude and intention models relating to ECS (Li \& Petrick, 2008). This is because each study is based on the object and different settings. These conditions provide opportunities to design an alternative model capable of elaborating on the phenomenon to be observed. The alternative model is built based on five variables, namely SQ, shipping cost, brand, and attitude, which explain their effect on the intention to choose ECS.

This research contributes to understanding SQ, shipping cost, and brand efect and their attributes that alter the consumer's will and intention to choose ECS in e-commerce. In an effort to give a clearer picture of the relationships between SQ, shipping cost, brand, and attitude which explain their effect on the consumer's intention to choose ECS in e-commerce, a SEM techniques analysis is employed to give a predictive answer.

\section{LITERATURE REVIEW}

Many researchers have been exploring the various markets in which the e-commerce strategy generates significant excess profit. In the context of online sales, SMEs contributed $57.84 \%$ of total transactions (As'ad \& Ahmad, 2012). The sharing economy business model contributes to the Indonesian economy. For example, a digital pilot business like GoJek with SME partners contributed a transaction volume of IDR 1.7 trillion in the 2017 period (Demographic Institute, 2018). This means that e-commerce and courier service sectors have a great potential for improvement.

\subsection{Attitude Towards Choosing a Courier Service}

Today, attitude occupies a central role in the theories and research regarding consumer behavior. An attitude is a relatively enduring organization of beliefs, feelings, and behavioral tendencies towards socially significant objects, groups or symbols (Hogg \& Vaughan, 2005). The attitude represents what one likes and dislikes or the amount of positive and negative feelings one has towards an object (Blackwell et al., 2001). Consumer attitudes have been and still are a key factor for companies. From a business perspective, consumer attitudes are responsible for an evaluation of a product or service and consequently the purchase or not of this product or service. 
Previous studies stated that consumer attitude determines the favorability of a person's intentions but not a given intention (Ajzen, 2001; Fishbein \& Ajzen, 1975). For example, two customers may hold the same attitude towards a service, but they may hold different intentions concerning their behaviors towards it. Regarding consumer attitude towards a service in general, previous studies claimed that attitude is an important factor in influencing consumers' intention towards the service (Chaniotakis et al., 2010). We have concentrated on uncovering the factors that affect the attitude towards choosing a courier service for shipments of goods purchased online. Consumers' attitude to online shopping is an important factor that influences the intention of online shopping (Andrews \& Bianchi, 2012). Attitudes toward online shopping are defined as a consumer's positive or negative feelings related to accomplishing the purchasing behavior on the internet (Chiu et al., 2005). In order to investigate consumers' attitudes, we need to know what their attitude to online shopping is.

Online shopping is defined as buying a basket of commodities and its related services (e.g. courier service) over the internet (Chaffey, 2009). A customer can be attracted to a shopping website or startup depending on its commodity, quality of service and finally payment security and privacy. These factors affect the consumer's attitude and intention when shopping online. In turn, the quality of service especially includes delivery time, quality of offered goods, and technology used for processing and delivering the consumer's orders (Meschi et al., 2011). Consumer attitude plays a central role in intentions to buy online and at the same time choose ECS. In the context of online shopping, the first dimension of attitudes is consumers' acceptance of the online mode as a shopping channel. The second dimension is consumer attitudes toward a specific online store and its courier service partners (Jahng et al., 2001).

We begin by considering the definition of attitudes because no measurement procedure can be designed until the construct of interest has been specified. Attitudes are individually attributed emotions, beliefs and behavioral tendencies an individual has towards a specific object. Attitude also varies in degrees, which impels individuals to react to the object.

Attitude is a construct of three components: cognitive, affective and conative (Jin, 2011; Rosenberg \& Hovland, 1995). Though most attitudes have all three components mentioned above, they can be more strongly rooted in either the cognitive or the affective component. One of the underlying assumptions about the link between attitudes and intention is that of consistency. This means that we often or usually expect someone's behavior intention to be consistent with the attitudes that they hold. The principle of consistency reflects the idea that people are rational and attempt to behave rationally at all times and that a person's behavior should be consistent with their attitude. Thus, attitude is used to see consistency as a mediation of customer goodwill. In this case, the researcher wanted to perceive the individual's desire through the attitude dimension as a mediating variable.

Hypothesis 1: Attitude towards choosing a courier service positively influences the intention to choose ECS.

\subsection{Service Quality}

Service quality (SQ) is a fundamental criterion of success for shipping companies which are focused on serving online shopping (Shankar et al., 2003); high SQ has been shown to boost online channel usage (Cho, 2004; Devaraj et al., 2002) and enhance customer satisfaction with websites of online companies that cooperate with an online-based shipping company (Xu et al., 2013). SQ is influenced by the expected service and the perceived service. If services are received as expected, SQ is satisfactory, but if the services received exceed their expectations, customers will be delighted and will perceive SQ as excellent and vice versa (Parasuraman et al., 1988).

The study of SQ was pioneered by marketing scholar Parasuraman (Parasuraman et al., 1988) and has been a long-standing and highly relevant construct within customer service contexts 
(Dabholkar \& Overby, 2005). According to these scholars, SQ is a consumer's global, subjective assessment of the quality of an interaction with a vendor, including the degree to which specific service needs have been met. SQ is based on the level of excellence in satisfying consumers' desires. The service company is required to improve the service as per consumer or consumers demand. So, improving SQ depends on the couriers' ability to consistently meet the needs as well as satisfy desires of consumers. Couriers can benefit and achieve competitive advantage by doing their best to create and maintain SQ, which can lead to consumer satisfaction. Thus, couriers must realize the strategic importance of quality, rather continuously upgrading quality as it is an investment that will generate greater profits in the future.

The evaluation of service is generally assessed through the SQ procedure known as SERVQUAL, which contains five dimensions: tangibles, reliability, responsiveness, assurance and empathy (Parasuraman et al., 2005). Several recent studies were conducted using the SERVQUAL model to examine SQ in different service-based organizations such as 313 members of the Korean Port Logistics Association (Yeo et al., 2015), 253 passengers of Dubai International Airport Terminal 3 (Hussain et al., 2015). These surveys reported that the capability of service providers to appropriately implement tangible, responsive, reliable, assured and emphatic dimensions in performing daily job had enhanced positive customer outcomes, especially customers' satisfaction. Despite its widespread application, it might not be suitable for measuring all aspects of the service provider due to different characteristics and features of SQ in the service industries. In other words, each sector of the service provider has its own characteristics.

Prior research on courier service found that most emphasized multiple components and conceptualized different dimensions. For example, in research on the business of courier service, Sze et al. (2013) suggest that the measure of SQ consists of three dimensions: (1) technical quality; (2) functional quality; and (3) image. Liu et al. (2014) indicate the ECS timeliness. Cakravastia and Takahashi (2004) and Kannan and Tan (2002) indicate the costs (e.g. freight rates and prices) and risk (reliability, losses, and collateral). The SQ assessment is mirrored by consumer perception on the ECS performance.

Hence, this study adopts the standards of the Global Express Association (GEA) to measure SQ. The GEA standard has been widely applied by courier companies in Europe and the United States (Oxford Economic Forecasting, 2009). The GEA standard consists of five dimensions as follows: global reach, reliability, transparency, speed, security. To apply the SQ framework to this research, the researchers have ensured that the selection of questions and dimensions of the framework are commensurate with the SQ of the courier company under investigation. For the purposes of the present research, SQ is measured by making use of the GEA standard. Accordingly, we have proposed the following hypothesis:

- Hypothesis 2: Service quality positively influences the attitude towards choosing a courier service.

\subsection{Shipping Cost}

Shipping cost was a critical factor for consumers in e-commerce (Heim \& Sinha, 2001). Basically, shipping cost is a fee applied to ship items to a buyer. As a seller lists an item, he or she can determine and disclose the shipping cost. The buyer can choose a courier company that is an e-commerce company partner and promises excellent service and competitive costs before payment is made.

E-commerce companies need to consider the cost of shipping and how it will be incorporated into pricing or passed along to consumers. The shipping service business has increased rapidly along with the rise of e-commerce. Shipping is defined as a package that contains items such as shoes, clothing or accessories that can be packaged and sent immediately to the customer (APS Fulfillment, Inc., 2017). 
The shipping cost is defined as all surcharge fees paid for shipping items to a the buyer. The separation of the shipping fee from the price of a product is an example of pricing where the total price is divided into components such as the base price and a surcharge (Hamilton et al., 2010). However, our focus is on the shipping cost in the context of e-commerce. It is considered important in the formation of the attitude toward ECS. This is due to the cost used by a consumer to evaluate both service and goods. In this research, the shipping cost needs to be investigated because there still is an inconclusive effect between shipping cost and intentions to choose ECS. The main reason why customers are unwilling to choose an ECS or switch from one to another is that the shipping charge is expensive.

Consumers are sometimes more sensitive to changes in the shipping charge than to changes in the price of the goods. According to the findings by Koukova et al. (2012), consumers are more sensitive to the price of partitioned components that are less important and provide relatively low consumption benefits (e.g., shipping) than to the price of components that are more important and provide relatively high consumption benefits (e.g., the product). On the contrary, the on-time delivery factor from ECS can be accepted by consumers even though they have to pay more for shipping costs (Rahman, 2006; Mentzer et al., 2001).

We have to take into consideration the fact that complaints are often voiced by consumers about the shipping cost. Shoppers often incur shipping charges when placing online orders and on average they pay $30 \%$ of their orders for shipping (Freedman, 2019). Therefore, it is important that there is a flat-rate shipping cost for shipping goods in online shopping. Some online shopping outlets offer flat-rate shipping to consumers. This makes it easier for consumers to understand how much they will be charged for shipping so they do not get surprised at the checkout time, and it helps stores anticipate how much they will spend on shipping costs.

Flat-rate shipping means that the price of shipping is not connected to the weight, shape, or size of the shipped item, hence the flat rate is based on how much you can stuff into the courier company-issued box. Flat-rate shipping involves a reasonable, rational, affordable, general and fair rate. According to Lopienski (2019), positive customer perceptions regarding flat-rate shipping can increase orders and are believed to increase the order value. Accordingly, we have proposed the following hypothesis:

- Hypothesis 3: Shipping cost positively influences the attitude towards choosing a courier service.

\subsection{Brand}

Today, brand is a powerful instrument of change. It is tightly connected with consumers and profoundly incorporated into their choices. Consequently, a company that owns a successful brand which is followed by loyal consumers have the power to shift consumers' attitudes and behavior. A challenging task for marketing managers of e-commerce companies and marketing managers of courier companies is to convince consumers that products purchased online are of good quality and will be sent immediately to the customer's address.

Brand is defined as a name, term, sign, symbol, or design or a combination of them, intended to identify the goods and services of one seller or group of sellers and to differentiate them from those of the competitor (Kotler, 2000). Another definition of a brand, stated by Burgess (2011), is a reason to choose. Both definitions imply that a company thinks about powerful brands that are built on singular positioning that is not only meaningful but relevant to its target consumer or Business to Customer (B2C). For example, consumers who buy our products are people who want to get the convenience from these products. Finally, consumers feel satisfied with the product and recommend other consumers to buy a specific product.

Often, in an e-commerce environment, brand is referred to the startup's and courier company's reputation as well consumer loyalty (Haig, 2001). Therefore, it should be concluded that brand 
is a perception in customers' minds of a good impression of a brand (Hawkins \& Coney, 2004). A good impression can arise if a brand makes an impression of being superior, popular, as well as a promising excellent service (Kotler \& Keller, 2012; Ogba \& Tan, 2009). Other researchers found that the attitude towards a brand had an effect on the product or service choice (Vahid \& Aidin, 2012). Accordingly, we have proposed the following hypothesis:

Hypothesis 4: Brand positively influences the attitude towards choosing a courier service.

\subsection{Intentions}

The notion of intentions to choose ECS is adopted from several earlier studies that designed intention as a dependent variable (Wang et al., 2010). The first attempt to formalize intention was made by Cohen and Levesque (1990). A choice is a consequence of the scenario which a consumer chooses to pursue. The choice is closed under a logical consequence which is the most preferred. Intentions are considered to be choices, but not all choices are intentions. Thus, an intention is the consumer's idea or plan to buy goods or use certain courier services, beginning with the use and acceptance of information technology to buy something in the future.

In this research, the concept of intention is analyzed by using the Technology Acceptance Model or TAM as developed by Davis et al. (1989). TAM is one of the most popular research models to predict the use and acceptance of information systems and technology by individual users. TAM represents an important theoretical contribution to understanding the behavior of the use and acceptance of information technology (Maholtra, 2007; Davis et al., 1989). The theoretical basis of the model was Fishbein and Ajzen's (2010), Theory of Reasoned Action or TRA. TRA is based on these three stages, namely beliefs, intentions, and actions with the following components: beliefs and aims of assessment, response to beliefs and motivation to follow behavior, attitudes towards behavior, subjective norms, and intentions to behave. Under the TRA, a decision to act is the best prediction of individual intentions.

TAM uses TRA as a theoretical basis for specifying causal linkages between two key sets of constructs: (1) Perceived Usefulness (PU) and Perceived Ease of Use (PEOU), and (2) user's attitude, behavioral intentions and actual information technology usage behavior. PU is defined as the consumer's subjective probability that using the internet will increase his or her benefit within an online transaction context. In turn, PEOU refers to the degree to which the consumer expects ease to use the internet for online transactions. Both PU and PEOU predict the attitude toward using information technology, defined as the consumer's desirability of his or her using the information technology. Attitude and PU influence the individual's behavioral intentions to use information technology. The actual use of information technology is predicted by behavioral intentions. According to TAM, ease of use and perceived usefulness are the most important determinants of the actual system use. Further, the attitude to use is concerned with the user's evaluation of the desirability of using a particular information technology platform. Intention is the measure of the likelihood of a person using the platform. The TAM model was adopted in this study because, as a model of the acceptance and use of technology, it has emerged as one of the most influential models. The TAM represents an important theoretical contribution toward understanding the platform usage and acceptance. Based on the attitude and intention preferences above, we have proposed the following hypothesis:

- Hypothesis 5: The attitude towards choosing a courier service mediates the effect of service quality, shipping cost, and brand on the customer's intention to choose ECS. 


\section{METHODOLOGY}

The research employs the intention model followed by the original exploratory method by Maholtra (2007). This method is adopted to explain the phenomenon observed in this study. The research was conducted in Jakarta using a survey technique. The questionnaire is used as a data collection tool. Each item in a variable was measured using a five-point Likert scale.

The population of the study consists of consumers who use ECS for shipment of items purchased online in Jakarta. The non-probabilistic samples were selected with the following criteria: (1) the respondents must have knowledge about the courier service which they intended to choose; (2) the respondents intended to choose ECS at SiCepat during September 17 - October 19, 2018. The determined size of the sample was 100 respondents, as a minimum criterion for the structural equation model / SEM (Hooper et al., 2008).

The SEM is used in this study because it has characteristics of an analysis technique to confirm whether a certain model is valid or not. The SEM is the preferred method for the mediation analysis (Vanderweele \& Vansteelandt, 2014). For the purposes of the SEM, specifically, mediation refers to a situation that includes three or more variables, such that there is a causal process between all variables. In a mediation relationship, possibly there is a direct effect between an independent variable and a dependent variable. There are also indirect effects between an independent variable and a mediator variable, and between a mediator variable and a dependent variable. When the analysis is carried out, it is possible to determine to what extent the attitude variable mediates the effect of service quality, shipping cost and brand on the intention to choose ECS.

\subsection{Validity of Instrument}

In the initial stages of statistical testing, the validity and reliability testing is carried out. Validity testing uses factor analysis techniques (Hair et al., 2006). Using construct validity, it is expected to find dimensions, indicators and strong items forming the construct of the tested variable. The item selection criteria are based on a factor analysis, with a degree of sample confidence or the Kaiser Meyer-Olkin Measure of Sampling Adequacy (KMO) value $>0.50$ if the KMO value is above 0.50 and a loading factor $>0.40$ (Hair et al., 2006), then a valid item can be further analyzed. In the aftermath of scrutinizing the reliability and also the validity of the scale, the researchers decided to test appropriateness of the collected data for the purpose of running a factor analysis. MacCallum et al. (2001) explained that if each and every communality is higher than 0.5 , then a comparatively small sample size of 100 is entirely sufficient.

Table 1

Validity value

\begin{tabular}{|c|c|c|}
\hline Construct & KMO value & Loading factor \\
\hline Attitude & 0.80 & 0.69 \\
\hline Service quality & 0.82 & 0.65 \\
\hline Shipping cost & 0.88 & 0.72 \\
\hline Brand & 0.81 & 0.67 \\
\hline Intention & 0.80 & 0.70 \\
\hline
\end{tabular}

Source: Author's elaboration.

The variation of KMO statistics is between 0 and 1. According to Field (2009), values that are greater than 0.5 are satisfactory. Therefore, values between 0.5 and 0.7 are second-rate, values between 0.7 and 0.8 are superior, and values between 0.8 and 0.9 are outstanding. The factor 
analysis in this study is outstanding and significant as its values are between 0.8 and 0.9 . The validity test results showed that all 50 items were declared valid, because all variables had a KMO value $>0.50$ and a loading factor $>0.4$. As a result of the analysis, it is recommended that the researchers should retain all variables planned at the beginning because of their validity.

\subsection{Reliability of Instrument}

The reliability value for all constructs of the five variables, namely: attitude, SQ, shipping cost, brand and intention exceeds 0.70 . The reliability test shows that the value of a for attitude is 0.83 ; the value of a SQ is 0.87 ; the value of a shipping cost is 0.75 ; the value of a brand is 0.82 and the value of a for intention is 0.79 . This shows that all questions can be used to collect data because the reliability of the instrument is satisfactory.

The reliability test is carried out to measure the reliability or internal consistency of a research instrument. The reliability test used is Cronbach's alpha coefficient, with a degree of reliability if Cronbach's alpha value obtained exceeds 0.7 , which is considered a good reliability value (Maholtra, 2004).

Table 2

Reliability value

\begin{tabular}{l|lcc}
\multicolumn{1}{c}{ Variables / Construct } & \multicolumn{1}{c}{ Number of items } & Corrected item & Cronbach's alpha $(\alpha)$ \\
\hline Attitude & 5 items & - & 0.83 \\
\hline Service quality & 25 items & - & 0.87 \\
\hline Shipping cost & 5 items & - & 0.75 \\
Brand & 5 items & - & 0.82 \\
\hline Intention & 5 items & - & 0.79
\end{tabular}

Source: Author's elaboration.

\subsection{Normality}

The normality of data in the study was tested by means of the Jarque-Bera statistical test. The results of the normality test are presented in Table 3 below.

Table 3

Normality test

\begin{tabular}{|c|c|c|c|c|c|}
\hline & Attitude & Service quality & Shipping cost & Brand & Intention \\
\hline Mean & 18.58 & 90.74 & 17.96 & 19.09 & 18.28 \\
\hline Median & 19.00 & 91.00 & 18.00 & 19.00 & 18.00 \\
\hline Maximum & 25.00 & 105.00 & 23.00 & 25.00 & 25.00 \\
\hline Minimum & 12.00 & 72.00 & 10.00 & 12.00 & 12.00 \\
\hline Std. Dev. & 2.78 & 8.02 & 2.45 & 2.66 & 2.63 \\
\hline Skewness & 0.05 & -0.44 & -0.29 & 0.01 & 0.20 \\
\hline Kurtosis & 2.50 & 2.58 & 3.17 & 2.80 & 2.53 \\
\hline Jarque-Bera & 1.08 & 3.93 & 1.49 & 0.16 & 1.59 \\
\hline Probability $(\boldsymbol{p})$ & 0.58 & 0.14 & 0.47 & 0.92 & 0.45 \\
\hline
\end{tabular}

Source: Author's elaboration. 
The results of the Jarque-Bera statistical test show the overall variable value $p>a=0.01$. This is a proof that the null hypothesis was accepted. This means that the variables of attitude, SQ, shipping costs, brand and intention are normally distributed, and are eligible for multiple regression.

\section{RESULTS}

For the demographic section, the respondents are divided into 5 different characteristics which are gender, age, level of education, employment as well as total annual household income. However, for the significance of the research, gender, age and total household income were analyzed. In terms of gender, $68 \%$ of the respondents are male and $32 \%$ are female.

In terms of age, $22 \%$ of the respondents are in the age range of $18-22$ years while $39 \%$ are $23-38,28 \%$ are $39-50$ and only $11 \%$ are 51 and above. The variations in the age percentages show that those in the age group of $23-38$, that is the millennial generation, choose ECS more often for shipping their goods purchased online.

In terms of the level of household income, $22 \%$ of low-income households choose ECS for shipping their online purchased goods. For middle-income households, 53\% choose ECS for shipping goods they buy online. In turn, $25 \%$ of high-income respondents choose ECS for shipping goods purchased online (see Table 4).

Table 4

Demographic characteristics of the sample $(n=100)$

\begin{tabular}{|c|c|c|c|}
\hline Characteristics & Categories & Frequency & Percent \\
\hline \multirow{3}{*}{ Gender } & Male & 68 & 68 \\
\hline & Female & 32 & 32 \\
\hline & Total & 100 & 100 \\
\hline \multirow{6}{*}{ Education } & Junior high school & 1 & 1 \\
\hline & Senior high school & 31 & 31 \\
\hline & Diploma & 16 & 16 \\
\hline & Undergraduate & 38 & 38 \\
\hline & Postgraduate & 14 & 14 \\
\hline & Total & 100 & 100 \\
\hline \multirow{5}{*}{ Age group } & $18-22$ & 22 & 20 \\
\hline & $23-38$ & 39 & 39 \\
\hline & $39-50$ & 28 & 28 \\
\hline & 51 and above & 11 & 13 \\
\hline & Total & 100 & 100 \\
\hline \multirow{5}{*}{ Employment } & Government employees & 41 & 41 \\
\hline & Private employees & 47 & 47 \\
\hline & Entrepreneurship & 9 & 9 \\
\hline & Other & 3 & 3 \\
\hline & Total & 100 & 100 \\
\hline \multirow{4}{*}{ Annual Household Income } & Low & 22 & 22 \\
\hline & Medium & 53 & 53 \\
\hline & High & 25 & 25 \\
\hline & Total & 100 & 100 \\
\hline
\end{tabular}


In Table 5, the measurement of indicators was presented as a means to find the main measures. The results for the measurement of the attitude towards choosing a courier service are shown by the following dimensions: like $(\alpha=.89)$, charmed by $(\alpha=.84)$, know about $(\alpha=.83)$, and happy with $(\alpha=.81)$. All four of them become the main measures of the attitude towards choosing a courier service. The results of the study show that speed with $\alpha=.89$ and reliability with $\alpha=.81$ are the main measures of SQ. The shipping cost shows that all the dimensions (e.g., fair rate, affordable rate, reasonable rate, rational rate and common rate) are the main measures. The measurements for brand are: famous brand $(\alpha=.87)$, familiar brand $(\alpha=.86)$, favorite brand $(\alpha=.80)$ and impression brand $(\alpha=.80)$, all four being the main measures. As for the measurement of the intention to choose ECS, the result showed reliable with $\alpha=.88$, friendly with $\alpha=.87$, and desirable with $\alpha=.84$ as primary measures of the intention to choose ECS.

Table 5

Measuring indicators

\begin{tabular}{|c|c|c|c|c|c|c|}
\hline Dimensions & Variables & Estimate & S.E. & $\alpha$ & C.R. & $\mathbf{P}$ \\
\hline Happy with & \multirow{4}{*}{$\leftarrow$} & .20 & .02 & .81 & 13.89 & $* * *$ \\
\hline Like & & .22 & .01 & .89 & 19.38 & $* * *$ \\
\hline Excited by & & .19 & .02 & .79 & 12.62 & $* * *$ \\
\hline Charmed by & & .18 & .01 & .84 & 15.43 & $* * *$ \\
\hline Know about & & .21 & .01 & .83 & 14.68 & $* * *$ \\
\hline Global reach & \multirow{4}{*}{$\leftarrow$} & .24 & .02 & .76 & 13.71 & $* * *$ \\
\hline Reliability & & .20 & .01 & .81 & 13.71 & $* * *$ \\
\hline Transparency & & .15 & .01 & .74 & 10.92 & $* * *$ \\
\hline Speed & & .22 & .01 & .89 & 19.84 & $* * *$ \\
\hline Security & & .19 & .02 & .73 & 10.48 & $* * *$ \\
\hline Reasonable rate & & .20 & .01 & .85 & 15.70 & $* * *$ \\
\hline Rational rate & o & .23 & .01 & .82 & 19.19 & $* * *$ \\
\hline Affordable rate & $\stackrel{\infty}{\Xi}$ & .20 & .01 & .88 & 14.28 & $* * *$ \\
\hline Common rate & 鸪 & .22 & .01 & .80 & 17.98 & $* * *$ \\
\hline Fair rate & & .16 & .01 & .89 & 13.18 & $* * *$ \\
\hline Favorite & \multirow{5}{*}{$\leftarrow$} & .22 & .02 & .80 & 13.47 & $* * *$ \\
\hline Superior & & .18 & .02 & .75 & 11.13 & $* * *$ \\
\hline Familiar & & .19 & .01 & .86 & 16.38 & $* * *$ \\
\hline Famous & & .21 & .01 & .87 & 17.93 & $* * *$ \\
\hline Impression & & .20 & .02 & .80 & 13.30 & $* * *$ \\
\hline Desirable & \multirow{5}{*}{$\leftarrow$} & .19 & .01 & .84 & 15.30 & $* * *$ \\
\hline Reliable & & .23 & .01 & .88 & 18.15 & $* * *$ \\
\hline Flexible & & .21 & .02 & .79 & 12.77 & $* * *$ \\
\hline Friendly & & .21 & .01 & .87 & 17.76 & $* * *$ \\
\hline Valuable & & .17 & .01 & .79 & 12.60 & $* * *$ \\
\hline
\end{tabular}

Note: $\mathrm{CR}=$ Critical Ratio

$* * * \mathrm{p}<.01$

Source: Author's elaboration. 
The SEM technique is applied to several dependent variables directly or indirectly related to consumers' intention to choose ECS in e-commerce simultaneously. Hypothesis testing using the SEM analysis is done to determine model suitability and items used in the research through an absolute test of goodness-of-fit. According to Hair et al. (2009), there are six tests that need to be done on a model that should be considered to reach the stage of absolute goodness-of-fit, where four of six tests indicate that the model has reached the stage of absolute goodness-of-fit. The SEM analysis shows that the six absolute goodness-of-fit tests are good and have met the model suitability requirement as follows: the probability values of chi-square ratio statistics 6.79 $(\mathrm{df}=3, \mathrm{p}=0.08)$; GFI $=0.97$; RMSEA $=0.08$; AGFI $=0.89$; CFI $=0.98$; and NFI $=0.97$. Thus, this model is declared eligible to be used as a tool to confirm the theory that has been put forward based on observational data.

Table 6

Determination of goodness-of-fit via SEM

\begin{tabular}{|c|c|c|c|c|c|c|c|}
\hline Model & Dk & $X^{2}(p)$ & GFI & RMSEA & AGFI & CFI & NFI \\
\hline $\begin{array}{l}\text { Attitude, service quality, shipping cost, } \\
\text { brand and intention }\end{array}$ & 3 & $\begin{array}{c}6.79 \\
(0.79)\end{array}$ & 0.97 & 0.83 & 0.89 & 0.84 & 0.97 \\
\hline
\end{tabular}

Note: GFI = Goodness-of-fit index, RMSEA = Root mean square error of approximation, AGFI = Adjusted goodness of fit index, CFI = comparative fit index, NFI $=$ normed fit index

$* * * \mathrm{p}<0.01$

Source: Author's elaboration.

Figure 1 shows that the coefficient value between SQ and attitude is 0.03 ; shipping cost and attitude is 0.15 ; brand and attitude is 0.64 ; while attitude towards intention is 0.76 .

Figure 1

Model of service quality, shipping cost, brand, attitude and intention
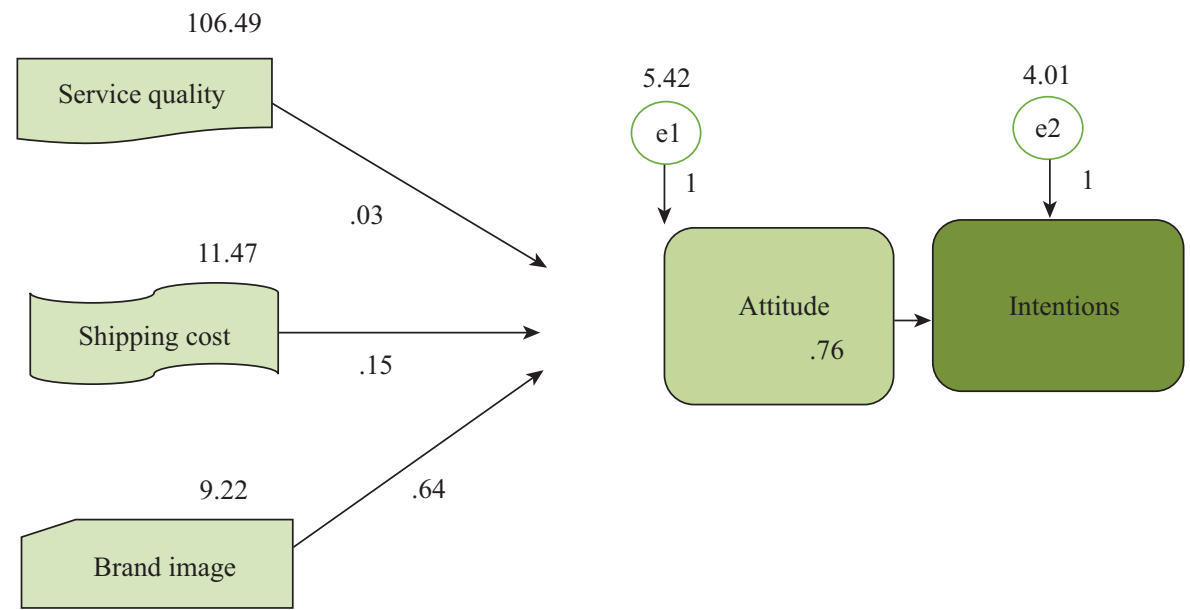

Source: Author's elaboration.

In this research, the hypotheses are tested by comparing $\mathrm{p}$-value $<0.01$ to determine the significance level. When $p$-value $<0.01$, then Ho is not supported, whereas if $p$-value is $>0.01$, Ho is supported. Table 7 shows the results of the test as follows.

As described, SQ does not influence the attitude towards choosing a courier service, although the effect is not significant as indicated by the p-value of $0.39>0.01$ and the regression coefficient of 0.03 , which indicate that increased SQ does not affect the attitude towards choosing a courier service. The critical ratio value is 0.86 , which indicates that no relationship effects were detected. Thus, the hypothesis stating that there is a positive influence of SQ on the attitude towards choosing a courier service is not supported. 
Furthermore, shipping cost does not influence the attitude towards choosing a courier service, although the effect is not significant as indicated by $p=0.07>0.01$ and the regression coefficient of 0.15 , which indicate that increased shipping cost does not affect the attitude towards choosing a courier service. The critical ratio value is 1.80 , which indicates that no relationship effects were detected. Thus, the hypothesis stating that there is a positive effect of shipping cost on the attitude towards choosing a courier service is not supported.

Brand is positively associated with the attitude towards choosing a courier service, which is indicated by a positive regression coefficient of 0.64 with the critical ratio at 6.06 and $p=0.00<0.01$. In other words, the results of this research show that brand has a significant effect on the attitude towards choosing a courier service. Thus, the hypothesis is supported. The attitude towards choosing a courier service also has a significant influence on the intention to choose ECS (regression coefficient of .76 with critical ratio at 12.61 and $p$-value $=0.00<0.01$ ); thus, the hypothesis that the attitude towards choosing a courier service positively influences the intention to choose ECS is supported.

Table 7

Path coefficients of variables

\begin{tabular}{llccccc} 
& Variables & Estimate & S.E. & C.R. & P \\
attitude & $\leftarrow$ & service quality & 0.03 & 0.03 & 0.86 & 0.39 \\
attitude & $\leftarrow \quad$ shipping cost & 0.15 & 0.08 & 1.80 & 0.07 \\
\hline attitude & $\leftarrow$ & brand & 0.64 & 0.11 & 6.06 & $* * *$ \\
intentions & $\leftarrow$ & attitude & 0.76 & 0.06 & 12.61 & $* * *$
\end{tabular}

Note: $\mathrm{CR}=$ Critical Ratio

$* * * \mathrm{p}<0.01$

Source: Author's elaboration.

This finding shows that indirect effects of SQ and shipping cost on the intention to choose ECS are very low, $\alpha=0.03$ and $\alpha=0.15$ respectively. Meanwhile, the indirect effect (via attitude) of brand on the intention to choose ECS is adequate, namely $\alpha=0.64$, while the direct effect of the attitude towards choosing a courier service on the intention to choose ECS is high, that is $\alpha=0.76$, thus, $\mathrm{H} 5$ is supported.

\section{DISCUSSION}

The findings suggest that the presence of SQ does not affect the customer's attitude towards choosing ECS. Although the SQ was measured using the standard GEA, which required shipping attributes including global reach, reliability, transparency, speed and security. It is found that speed and reliability are SQ main measures. This proves that SiCepat is known as a courier company that fulfills its promises of reliability and speed of shipment of goods. The findings of this research are somehow similar to other research (e.g., Liu et al., 2014; Cakravastia \& Takahashi, 2004; Kannan \& Tan, 2002). Indeed, SQ is assessed by the customer's perception of ECS performance.

The results of this study disprove the idea that shipping cost positively influences the attitude towards choosing a courier service, which is exactly consistent with the findings of previous empirical studies (Rahman, 2006; Mentzer et al., 2001). Further, the study identifies five dimensions that affect the shipping cost, namely: fair rate, affordable rate, reasonable rate, rational rate, and common rate. The identified shipping cost dimensions are consistent with the shipping cost cluster identified by Lopienski (2019), which is known as a flat rate. 
Brand affects the attitude towards choosing a courier service, which means that there is an effect of a respective brand on the attitude towards choosing a courier service. The brand indicators show that a famous brand, familiar brand, favorite brand and impression brand are the main measures. This result supports Kotler and Keller's (2012) ideas that quality perception can show a superior differentiation of services and makes consumers selectively use brands and services. Besides, the company's brand affects a positive attitude towards choosing a courier service and customers' intention to choose ECS, which is in line with Ogba and Tan's (2009) investigation indicating that brand affects attitude. Good customer perception can be developed if the brand has a unique advantage and good reputation, provides the best service as well as is good and popular (Kotler \& Keller, 2012).

The results of this study confirm that the attitude towards choosing a courier service positively influences the intention to choose ECS, which is consistent with the findings of previous empirical studies (Meschi et al., 2011; Chaniotakis et al., 2010). Furthermore, the study identifies five attitude dimensions that affect the attitude towards choosing a courier service, namely: like, charmed by, know about, happy with and excited by, which are strongly rooted in either the cognitive or the affective component. The identified several attitude dimensions are consistent with the attitude cluster identified by Chaffey (2009).

In this research, the intention is analyzed by using the TAM to find causal linkages between two key sets of constructs as follows: reliability and flexibility are elements of the PU and userfriendliness of technology is used as an element of PEOU. Other constructs of intention such as the user's attitude and behavioral intentions are reflected by one's perceived likelihood that one will engage in a given behavior such as using the technology.

Moreover, we have found that there is no direct effect of SQ and shipping cost on the consumer's intention to choose an ECS. On the other hand, brand exerts a direct effect (via attitude) on the consumer as regards choosing an ECS, while the attitude towards choosing a courier service has a strong direct effect. In short, the attitude towards choosing a courier service acts as a mediator amongst SQ, shipping cost and brand towards the intention to choose an ECS.

\section{CONCLUSIONS}

To summarize, we have found that there are effects between variables in the SEM. In general, SQ and shipping cost do not affect customers' attitude towards choosing a courier service. Their attitude towards using a courier service is affected by the brand. Furthermore, this research confirms the link between brand and their attitude, it has been found that the indicators of brand can change the positive attitude of the customer. It can be concluded that brand directly describes the quality of goods received. However, although both brand and customers' attitude towards choosing a courier service exert an adequate effect on customers' intention to choose ECS, the effect of customers' attitude towards choosing a courier service on customers' intention to choose ECS is higher than that of brand.

It is also proved that the mediating role of customers' attitude towards choosing a courier service as regards the intention to choose ECS has sharpened the previous attitude models in the cyberspace context. The construct of cognitive, affective and conative elements can explain individual desires to determine a positive attitude. The construction of a positive attitude towards choosing a courier service is a critical factor closely related to the SQ perceived, the flat rate of shipping cost and the brand which is offered.

Finally, this research found that the attitude towards choosing a courier service is a mediator of the relationship between SQ, shipping cost, brand and intention to choose ECS. Thus, the advantage of this research lies in lies in the adoption of the main model of service quality 
standards set by the GEA and used globally, which require the attributes of global reach, reliability, transparency, speed and security in support of the e-commerce business.

\subsection{Managerial Implications}

Significantly, a number of managerial implications discussed in this research are relevant to these three major areas, namely SQ, shipping cost and brand. We structure the implications in three facets as follows.

The confirmation of the research model has the potential to help managers better understand how customers assess the SQ. The results from the study suggest that SQ should be measured to fully capture an individual's overall perception of SQ. Traditionally, SQ is no longer a problem because it is believed that customers already know the company's performance, either from previous experience or recognition from others. One implication of these findings for managers of both e-commerce and courier companies is to assess the organizational image as part of an assessment of perceptions of SQ. A positive image makes it easier for a firm to communicate effectively, and it makes people more perceptive to favorable messages.

The implication is that while the flat rate of shipping cost has no effect in terms of consumers' attitude towards choosing a courier service, there may be a negative effect in that consumers purchase goods online, where these items are available in several stores. This resulted in consumers having to pay shipping costs for several packages of goods that they had bought. The idea that the flat rate of shipping cost may make consumers satisfied applies only if e-commerce companies can coordinate producers of goods of various types for the closest area. So that consumers only pay the cost of shipping goods in one package. Drawing attention away from shipping costs may encourage consumers to scale up their order values and complete the online purchase process.

The proposed model and the empirical results have several important implications for the practice of business-to-business management. For the first time, the empirical results confirm the intuitively reasonable idea that brand is vital to market success in the business sector, having a clear positive direct effect on the attitude towards choosing a courier service and an indirect one on customers' intention to choose ECS. Small and medium-sized companies organized in e-commerce particularly need to catch up with business-to-consumer levels of brand. The study also emphasizes the importance of internal implementation of the branding concept and brand within both e-commerce and courier companies. The model further contributes to the prognosis of the brand's future by recommending a process for the implementation of brand strategy. Companies also need to pay attention to the composition of their brand teams and be aware of their strengths and weaknesses, but this will require emphasis on integration to arrive at congruent brand perceptions.

\subsection{Limitations and Future Work}

This study also has certain limitations. First, this research analyzes the effect of attitude towards choosing a courier service, SQ, shipping cost, brand and intention to choose ECS. Because there might be some other variables which can affect the intention to choose ECS, the author strongly suggests that in the future research, these other variables should be explored and analyzed as well an indicators in this study need to be more widely developed. Second, this research has been conducted exclusively on courier companies serving the shipping of goods purchased from e-commerce companies and the results and conclusions of this research might not be generalizable to other industries. Third, due to a shortage of time, the researchers did not manage to select a greater number of subjects to meet the requirement of a large sample size. Those who were chosen from Jakarta only could not represent the whole population of Indonesian 
customers. Therefore, future research should be done with an increased sample size with various characteristics.

\section{References}

Ajzen, I. (2001). Nature and operation of attitudes. Annual Review of Psychology, 52, 27-58.

Andrews, L., \& Bianchi, C. (2012). Consumer internet purchasing behavior in Chile. Journal of Business Research, 66(10), 1791-1799.

As'ad, I., \& Ahmad, F. (2012). An empirical study of e-commerce implementation among SME in Indonesia. International Journal of Independent Research and Studies, 1(1), 13-22.

Blackwell, D.R., Miniard, W.P., \& Engel F.J. (2001). Consumer Behavior ( $9^{\text {th }}$ ed.). South Western: Thomson Learning.

Cakravastia, A., \& Takahashi, K. (2004). Integrated model for supplier selection and negotiation in a make-to-order environment. International Journal of Production Research, 42(21), 4457-4474.

Chaffey, D. (2009). E-business and e-commerce management strategy, implementation and practice (5 ${ }^{\text {th }}$ ed.). Essex: Pearson Education Limited.

Chaniotakis, I.E., Lymperopoulos, C., \& Soureli, M. (2010). Consumers' intentions of buying own-label premium food products. Journal of product and Brand Management, 19(5), 327-334.

Chiu, Y.B., Lin, C.P., \& Tang, L.L. (2005). Gender differs: Assessing a model of online purchase intentions in e-tail service. International Journal of Service Industry Management, 16(5).

Cho, J. (2004). Likelihood to abort an online transaction: Influences from cognitive evaluations, attitudes, and behavioral variables. Information \& Management, 41, 827-838.

Cohen, P. R., \& Levesque, H. J. (1990). Intention is choice with commitment. Artificial Intelligence, 42(2-3), 213-261. https://doi.org/10.1016/0004-3702(90)90055-5.

Demographic Institute. (2018). The impact of Go-Jek on the Indonesian economy. Jakarta: Demographic Institute, University of Indonesia.

Dabholkar, P.A., \& Overby, J.W. (2005). Linking process and outcome to service quality and customer satisfaction evaluations: An investigation of real estate agent service. International Journal Service Industry Management, $16(1), 10-27$.

Davis, F.D., Bagozzi, R.P., \& Warshaw, P.R. (1989). User acceptance of computer technology: A comparison of two theoretical models. Management Science, 35, 982-1003.

Devaraj, S., Fan, M., \& Kohli, R. (2002). Antecedents of B2C channel satisfaction and preference: Validating e-commerce metrics. Information Systems Research, 13(3), 316-334.

Field, A. (2009). Discovering Statistics using SPSS. Sage: London.

Fishbein, M., \& Ajzen, I. (1975). Belief, attitude, intention, and behavior: An introduction to theory and research. Reading, MA: Addison-Wesley.

Fishbein, M., \& Ajzen, I. (2010). Predicting and changing behavior: The reasoned action approach. New York: Psychology Press Taylor.

Haig, M. (2001). The e-marketing handbook. Dover, NH: Kogan Page.

Hair, J.F. (2009). Multivariate data analysis (9th ed.). New Jersey: Pearson Education.

Hamilton, R.W., Srivastava, J., \& Abraham, A.T. (2010). When should you nickel and dime your customers? A manager's guide to benefits-based price partitioning. MIT Sloan Management Review, 52(1), 59-67.

Hawkins, D.I., Best, R.J., \& Coney, K.A. (2004). Consumer behavior - Building marketing strategy. New York: McGraw-Hill.

Heim, G.R., \& Sinha, K.K. (2001). Operational drivers of customer loyalty in electronic retailing: An empirical analysis of electronic food retailers. Manufacturing and Service Operations Management, 3(3), 264-271.

Hogg, M., \& Vaughan, G. (2005). Social Psychology (4th ed.). London: Prentice-Hall.

Hooper, D., Coughlan, J., \& Mullen, M. (2008). Structural equation modelling: Guidelines for determining model fit. Electronic Journal of Business Research Methods, 6(1), 53-60.

Hussain, R., Al Nasser, A., \& Hussain, Y.K. (2015). Service quality and customer satisfaction of a UAE-based airline: An empirical investigation. Journal of Air Transport Management, 42, 167-175.

Jahng, J., Jain, H., \& Ramamurthy, K. (2001). The impact of electronic commerce environment on user behavior: The case of a complex product. E-Service Journal, 1(1), 41-53.

Jin, Ch.-H. (2011). The role of animation in the consumer attitude formation: Exploring its implications in the tripartite attitudinal model. Journal of Targeting, Measurement and Analysis for Marketing, 19, 99-111.

Kannan, V.R., \& Tan, K.C. (2002). Supplier selection and assessment: Their impact on business performance. Journal of Supply Chain Management, 38(4), 11.

Kotler, P. (2000). Marketing management (Millenium Edition, $10^{\text {th }}$ ed.). New Jersey: Prentice-Hall, Inc. 
Kotler, P., \& Keller, K.L. (2012). Marketing management (14th ed.). New Jersey: Pearson-Prentice Hall.

Koukova, N.T., Srivastava, J., \& Steul-Fischer, M. (2012). The effect of shipping fee structure on consumers' online evaluations and choice. Journal of the Academy of Marketing Science, 40, 759-770. http://dx.doi. org.i.ezproxy.nypl.org/10.1007/s11747-011-0281-2.

Li, X., \& Petrick, J. (2008). Reexamining the dimensionality of brand loyalty: A case of the cruise industry. Journal of Travel and Tourism Marketing, 25, 68-85. DOI: 10.1080/10548400802164913.

Liu, J., Wei, L., \& Yuhong, L. (2014). Express company's vehicle routing optimization by multiple-dynamic saving algorithm. Journal of Industrial Engineering and Management, 7(2), 390-400.

MacCallum, R.C., Widaman, K.F., Preacher, K.J., \& Hong, S. (2001). Sample size in factor analysis: The role of model error. Multivariate Behavioral Research, 36(4), 611-637.

Malhotra, N.K. (2004). Marketing research. Prentice Hall: New Jersey.

Malhotra, N.K. (Ed.). (2007). Review of marketing research (Vol. 3). New York: Routledge.

Mentzer, J.T., Flint, D.J. \& Hult, G.T.M. (2001). Logistics service quality as a segment customized process. Journal of Marketing, 65, 82-104. http://dx.doi.org/10.1509/jmkg.65.4.82.18390.

Meschi, M., Irving, T., \& Gillespie. M. (2011). Intra-Community cross-border parcel delivery. A study for the European Commission. London: FTI Consulting Limited.

Ogba, I., \& Tan, Z. (2009). Exploring the impact of brand image on customer loyalty and commitment in China. Journal of Technology Management in China, 4(2), 132-144. https://doi.org/10.1108/17468770910964993.

Parasuraman, A., Zeithaml, V.A., \& Berry L.L. (1988). SERVQUAL: A multiple-item scale for measuring consumer perceptions of service quality. Journal of Retail, 64(1), 12-40.

Parasuraman, A., Zeithaml, V.A., \& Malhotra, A. (2005). ES-QUAL: A multiple-item scale for assessing electronic service quality. Journal Service Research, 7(3), 213-233.

Rahman, S. (2006). Quality management in logistics: An examination of industry practices. Supply Chain Management: An international Journal, 11(3), 233-240.

Rosenberg, M.J \& Hovland, C.I. (Eds.). (1995). Attitude organization and change: An analysis of consistency among attitude components. New Haven, Connecticut: Yale University Press.

Shankar, V., Smith, A.K., \& Rangaswamy, A. (2003). Customer satisfaction and loyalty in online and offline environments. International Journal of Research in Marketing, 20, 153-175.

Sze, H.C., Keng, L.S., \& Wai, P.W. (2013). Impact of switching costs on the tripartite model - Third party logistics. Journal Management, 3(2), 79-88.

Vahid, R., \& Aidin, T.N. (2012). The role of attitudes and decision making on product choice case study: Cellulars phones. International Business Research, 5(5), 32-146.

Vanderweele, T.J., \& Vansteelandt, S. (2014). Mediation analysis with multiple mediators. Epidemiologic Methods, 2, 95-115. http://dx.doi.org.i.ezproxy.nypl.org/10.1515/em-2012-0010.

Wang, Y.S., Lin, H.H., \& Liao, Y.W. (2010). Investigating the individual difference antecedents of perceived enjoyment in the acceptance of blogging. World Academy of Science, Engineering and Technology, 4(7), 1798-1807.

Xu, J.D., Benbasat, I., \& Cenfetelli, R.T. (2013). Integrating service quality with system and information quality: An empirical test in the e-service context. MIS Quarterly, 37(3), 777-794.

Yeo, G.T., Thai, V.V., \& Roh, S.Y. (2015). An analysis of port service quality and customer satisfaction: The case of Korean container ports. The Asian Journal of Shipping and Logistics, 31(4), 437-447.

\section{Internet sites:}

APS Fulfillment, Inc. (2017). 6 insider secrets to save time and money with your product fulfillment. Retrieved on 8 October 2018 from https://www.apsfulfillment.com/shipping-fulfillment/ what-is-the-difference-between-shipping-and-delivery/.

Burgess, C. (2011). What is a brand? Blue focus marketing. Retrieved from https://bluefocusmarketing. com/2011/02/14/what-is-a-brand.

Freedman, L. (2019, March 19). The shopper speaks: Does anyone really pay for shipping? Listrak. Retrieved from https:// www.digitalcommerce360.com/2019/03/19/the-shopper-speaks-does-anyone-really-pay-for-free-shipping/.

InvestorDaily. (2017, February 13). SiCepat Ekspres Sudah Kerja Sama dengan 4.600 Toko Online. Retrieved on 14 June 2018 from https://www.beritasatu.com/iptek/414232/ sicepat-ekspres-sudah-kerja-sama-dengan-4600-toko-online.

Lopienski, K. (2019, April 11). Understanding USPS flat rate shipping for ecommerce. ShipBob. Retrieved from https://www.shipbob.com/blog/flat-rate-shipping/.

Oxford Economic Forecasting. (2009). The impact of the express industry on the global economy. Unpublished report. Retrieved on 14 June 2018 from http://www.oef.com. Feb 25, 2015. 